\title{
BREXIT and the Implications of Food Safety Cultural Compliance in the Food Manufacturing Sector
}

\section{Derek Watson ${ }^{1 *}$, Stanley Yap ${ }^{2}$, Sophia Pandi ${ }^{3}$, John Husband ${ }^{4}$ and Fanos Tekelas ${ }^{5}$}

${ }^{1}$ Senior Lecturer, University of Sunderland, UK

${ }^{2}$ Associate Professor, SEGi University, Malaysia

${ }^{3} P h D$ Research Student, University of Sunderland, UK

${ }^{4}$ Director, Consultancy and e-Learning, Totrain Company, UK

${ }^{5}$ Research Fellow, The Cyprus School of Business, UK

*Corresponding Author: Derek Watson, Senior Lecturer, University of Sunderland, UK.

Received: February 23, 2018; Published: March 21, 2018

DOI: 10.31080/ASMI.2018.01.0039

\begin{abstract}
In theory food safety is a critical measurement, not just for economic and legal reasons but also for the moral integrity of the organisation. However, in reality, the number of accidents or incidents particularly in the food manufacturing sector is a serious cause for concern. The problem is further compounded with the onset of Brexit. Given the UK government's floundering negotiation talks and the pending conservative leadership challenge, it has resulted in a climate of uncertainty, a devaluation of currency and economic instability. Food manufacturers along with other commercial businesses are reluctant to further invest until the economic future is more transparent. In consequence, food manufacturers are seeking efficiency savings, whilst aiming not to compromise food safety compliance. Whilst there are areas of best practice, sadly there are an increasing number of examples in which failure to comply to food safety is resulting in lost of business, serious injury and in certain cases fatalities. This paper addresses Food Safety Cultural Compliance within UK Food Manufacturers and identifies core issues that hinder the establishment of a proactive food safety culture. The research study adopts a mixed methods approach in which five UK food manufacturers were consulted via 15 semi-structured interviews with management and three focused groups. The data collected clearly indicates a commitment to food safety compliance. However, the majority of organisations struggled to maintain consistent levels of food safety compliance despite implementing costly training and development initiatives. Their strategic and operational drive to both enhance and maintain a positive food safety culture was also undermined with the uncertainty of economic pressures and the quagmire of Brexit. The paper concludes with a series of commercially viable recommendations within the context of the Brexit divorce and provides a clear contribution to the community of practice.
\end{abstract}

Keywords: Brexit; Food-Manufacturers; Food-Safety; Culture; Compliance

\section{Introduction}

In 2013, the British Prime Minister David Cameron stated that the British people must "have their say" on Europe if the Conservative party won the next general election [1]. The 2015 election results ensured that the Conservative party would continue to govern the country with a 12-seat majority and ensured that they would honor their manifesto commitment. Whilst governmental analysts stated that the vote would be tight, there was a general consensus amongst party officials that the vote would be to stay in Europe. However, on June $23^{\text {rd }} 2016$ the British electorate defied the analysts and voted to withdraw from the European Union by $52 \%$ to $48 \%$ majority. Former Prime Minster Cameron in a speech to students at DePauw University, USA, described the Brexit vote, Donald Trump's election and the Italian referendum as a movement of unhappiness, driven by populism [2].
The vote to leave the EU in the signing of Article 50 of the Lisbon Treaty was greeted by insecurity. Ex-Sainsbury's CEO Justin King said Brexit will lead to "higher prices, less choice and poorer quality at supermarkets" [3]. On June $24^{\text {th }} 2016$ the pound suffered its worst day dropping to $\$ 1.3236$, a fall of more than $10 \%$. Both the FTSE 100 index and the more UK-focused FTSE 250 fell more than $8 \%$. The devaluation of the pound had a domino effect in that it forced the annual inflation rate of $0.5 \%$ up to $2.9 \%$ [4]. This in turn slowed wage growth into a decline that resulted in a contraction of consumer spending and categorised the UK as the slowest growing economy in the G7 [5].

It was not just the currency traders who were unprepared, businesses were also anxious about the future. The effects of the 2008 recession are still evident in the economy and the Brexit instability has resulted in a very unpredictable economic landscape. 
The agri-food sector is equally nervous about potential immigration controls, as it contributes $£ 103$ billion or $7.6 \%$ to the national Gross Value Added in 2013 and employs 3.8 million people. EU nationals contributed $7 \%$ (2.2 million $+/-0.1$ million) and non-EU nationals $4 \%$ (1.2 million $+/-0.1$ million) [6].

\section{Literature Review}

71 of the UK's largest food companies have stated "Maintaining tariff-free access to the EU single market is a vital priority. It is where $75 \%$ of our food exports go, so all our farming and food businesses wish to maintain this outcome". They have lobbied the government stating that it is imperative that the government needs to negotiate the "best possible access" [7]. The statement was signed by the National Food Union in England, Scotland and Wales as well as the Ulster Farmers Union and leading food businesses that have a combined turnover of over $£ 92$ billion (approximately $€ 110$ billion) and employing over 925,000 people across the UK. Signatories included the heads of Sainsbury's, Morrisons, Marks and Spencer and Weetabix [8].

The International Monetary Fund (IMF) has also expressed grave concerns over the lack of clarity concerning Brexit and in consequence poses a real risk to global financial stability [9]. There is further tangible evidence of business insecurity over Brexit, as many banks such as Morgan Stanley, Citigroup Inc., Deutsche Bank $\mathrm{AG}$ and JP Morgan Chase and Co are now operating on a worst-case scenario and state they will relocate their staff and operations to better serve their EU client base [10]. Thus, the stark message from the economy is the urgent desire for stability. If not, then the trappings of relocating to Amsterdam, Dublin, Frankfurt, Luxembourg and Paris may prove attractive for businesses [11].

Triggering Article 50 of the Treaty on the EU has started a 'ticking clock' towards the UK's final exit from the EU on March $29^{\text {th }}$ 2019. However, the slow Brexit negotiations are doing little to put the UK industry, in particular, food manufacturers at ease [12]. Furthermore, the Great Repeal Bill White Paper [13] will revoke the 1972 European Communities Act that took Britain into the EU and meant that European law took precedence over laws passed in the UK Parliament. It will also end the jurisdiction of the European Court of Justice. Thus, all existing EU legislation will be copied across into domestic UK law to ensure a smooth transition on the day after Brexit. However, currently it offers vague guidance concerning the future legal framework of UK law, and no clarity of how it might transform post Brexit.

To further fuel business fears, the government is still refusing to publish its Brexit impact assessment [14]. It is therefore the view that the post Brexit food world will be characterised by volatility, disruption and uncertainty [15]. Optimists hope that this will provide a much-needed mechanism to introduce improvements. Whilst eurosceptic neoliberals have an alternative agenda, they very much believe that change will enable them to abolish the many laws and provisions that they dislike and are perceived as burdens on producers and food businesses [16]
The main tenor of debate is whether the UK will seek a 'hard' Brexit or 'soft' Brexit deal. A hard Brexit scenario would most probably result in the UK relinquishing its full access to the single market and the customs union along with the EU. Thus, the UK would regain full control over its borders, negotiating new trade deals and applying laws within its own territory. In all probability, the UK would initially rely on World Trade Organisation (WTO) rules for trade with its former EU partners. However, leaving the customs union would mean a significant increase in bureaucratic checks on goods passing through ports and airports and a likely $10 \%$ tariff on EU goods [17].

Whilst a 'soft' Brexit would enable the UK to negotiate a relationship with the EU as close as possible to the current trading arrangements, the UK would not be a member of the EU, lose its MEPs, its European Commissioner and have no seat within the European Council. However, it would retain access to the European single market. Thus, goods and services would be traded with the remaining EU states on a tariff-free basis and financial firms would keep their "passporting" rights to sell services and operate branches in the EU. Britain would also remain within the EU's customs union, meaning that exports would not be subject to border checks, and it is the preferred choice of the UK remainders [18]. However, the implications of Brexit for food are potentially enormous. This verdict applies, whether there is a 'hard' or 'soft' Brexit. The UK food system has been thoroughly 'Europeanised'. Thus, many perceive that it will be impossible to cut back or quash by March 2019 without enormous consequences [19].

Stepping back from the limelight of Brexit, UK food manufacturers are constantly challenged in their fight against food contamination and the pursuit of employee food safety compliance. In the main food manufacturers recognise that good food safety cultures are instrumental for three good reasons, namely: it makes good economic, legal and moral sense [20]. However, despite the commitment of the vast majority of food organisations, the statistics are quite concerning. For instance, there were approximately 500 deaths a year caused by food-borne illnesses. Campylobacter was the most common food-borne pathogen, with about 280,00 cases every year and Salmonella is the pathogen that causes the most hospital admissions - about 2,500 each year. Ignoring the social cost, food contamination costs the UK nearly $£ 1.5$ billion a year [21].

Upon closer inspection, more than half of the incidents (see figure 1 and 2) in 2014 were reported by local authorities (403), EU Member States and the European Commission (246) or central government bodies (266). In September 2014, 61\% of incidents originated within the United Kingdom and almost all connected to environmental contamination incidents. Another $9 \%$ of incidents were related to foods from the rest of the EU, while about $21 \%$ were due to imported foods from outside. The origin of the remaining $9 \%$ could not be identified. In additional, action taken to protect consumers in relation to food safety included issuing 
90 alerts and information notices to local authorities. The FSA also sent 279 notifications to the European Commission via the Rapid Alert System for Food and Feed (RASFF) [21].

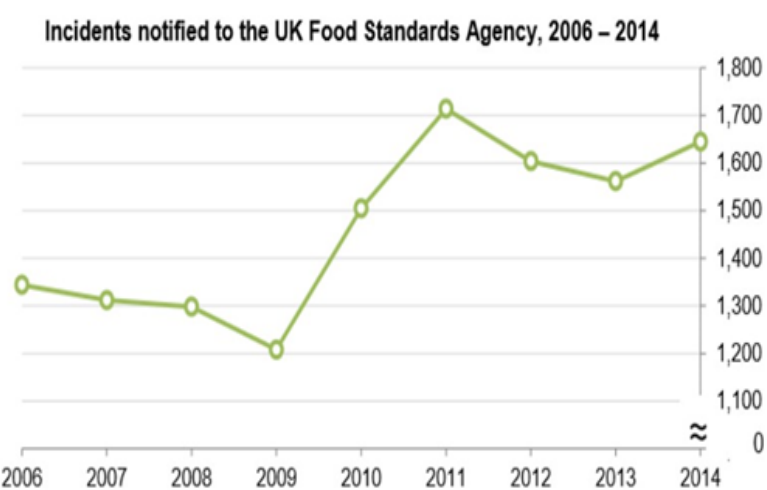

Figure 1: Incidents notified to the Food Standards Agency 2006 - 2014.

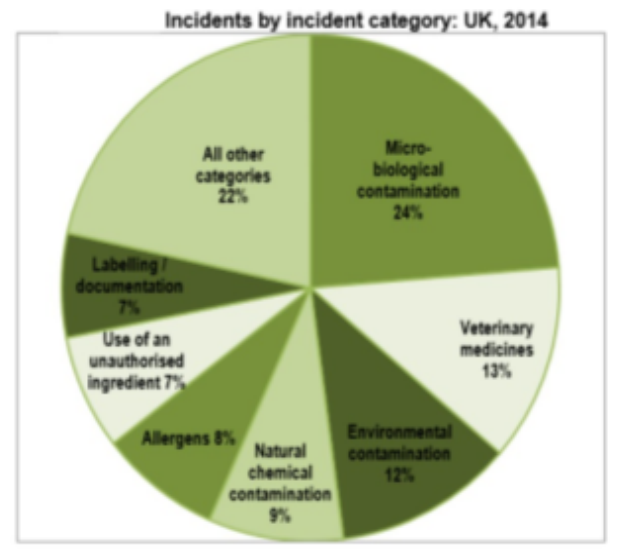

Figure 2: Incident Category: UK 2014.

In 2014, the FSA was notified of and investigated 1,645 incidents that reflected similar trends for 2012 and 2013. However, overall the frequency of reported incidents has increased over the last nine years. There were also 301 more incidents reported in 2014 than in 2006 and a total of 419 prosecutions in total. Just over 1 in 4 food law breaches $(26 \%)$ related to cleaning offences, where food enforcement officers found there was a failure by businesses to keep premises or equipment clean. Other common food law breaches included unfit food on premises, a lack of hand washing facilities and food safety training as well as pest control issues [21].

Microbiological contamination is the only category where incidents have been consistently increasing over time, from 147 in 2006 to 390 in 2014. In 2014, almost a third of microbiological contamination incidents (32\%) resulted from shellfish operations. High counts of Escherichia coli (E. coli) are used as an indicator of poor hygiene conditions in harvesting areas (see figure 3). Natural chemical contamination such as Algal toxins and mycotoxins (mainly aflatoxin) accounted for $87 \%$ of natural chemical contamination incidents in 2014, as mycotoxins can arise from certain moulds growing on cereals, nuts, spices and other foodstuffs. Algal toxins are also the direct result of naturally occurring algal blooms and are potential contaminants of shellfish [21].

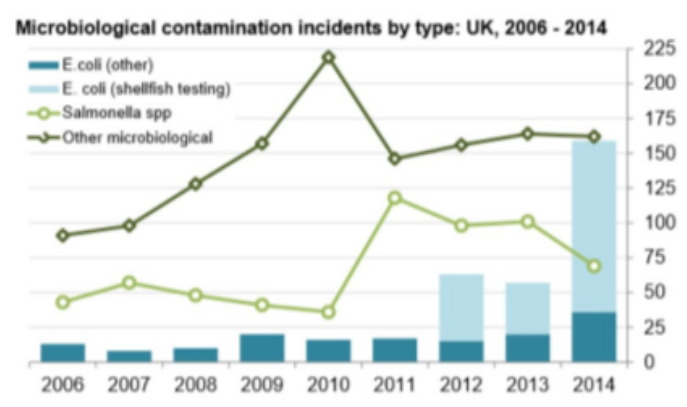

Figure 3: Microbiological contamination incidents by type: UK, 2006 - 2014.

T.S. Eliot stated that 'between the idea and reality falls the shadow' and the same can be said about a good food safety culture. As noted previously, the contamination statistics are not encouraging and there are numerous high-profile breaches which reflect noncompliance with food safety standards. For example, CRF Frozen Foods recalled over 350 different CRF Frozen Foods and Garland Ventures Limited brands, due to suspected food contamination with listeria monocytogenes bacteria, which can cause serious infections in children and the elderly as well as others with immune system issues. David Pitt of 'The Associated Press' described it as "one of the largest food recalls in recent memory", which has so far resulted in the laying off of just over 300 of their estimated 430 employees [22]. A second example to emphasize the point was in relation to Mars, who initiated an international recall of a range of chocolate bars, after a customer found a piece of red plastic in a Snickers bar bought in Germany. The recall, which affects 55 countries, could end up costing the company tens of millions of dollars [23].

Culture is an instrumental factor in nurturing organisational food safety compliance and is regulated by senior management rather like a thermostat [24]. Whilst most management recognise its importance as a proven determinant to organisational prowess management often overestimate the level of employee commitment and underestimate the level of resources needed [25]. Food safety culture, if it is to be effectively embedded within an organisation, cannot be seen as a one-off initiative but a life-long organisational commitment [26]. In essence, whilst it continues to be a hot topic of debate, and although many organisations globally have fit-for-purpose and quality compliant food safety management systems (FSMS) such as ISO 22000, Hazard Analysis and Critical Control Points (HACCP) and BRC Global Food Standards, they at worst fail or at best struggle to foster a sustained and proactive culture in the fight against food-borne outbreaks and employee food safety compliance [27]. Fundamentally it is harnessing the human dimension that is a complex and ever-changing issue that organisations face within the looming Brexit quagmire.

The number of definitions describing culture is vast with no apparent indication of losing its momentum. [28] aptly builds upon previous efforts in describing culture as "the beliefs, values, attitudes, behaviours and practices that are characteristic of a group of people". Alternatively, Deal and Kennedy [29] in no way underestimate the importance of culture but simply describe it as the "way we do things around here". However, Weigmann., et al. [30] was one of the pioneers who actively emphasised the importance 
of safety culture and identified seven common proactive themes found in safety culture literature (See Table 1). Weigmann., et al. [31] subsequently synthesised five factors that are in the main agreed to reflect a safety culture, namely: organisational commitment, management involvement, employee empowerment, reward systems and reporting systems.

1. Refers to shared values among a group or organisation.

2. Is concerned with formal safety issues and is closely related to but not restricted to management and supervisory systems.

3. Emphasises the contribution of everyone, at all levels in an organisation.

4. Impacts how individual members of the organisation behave at work.

5. Is reflective in contingency between reward systems and safety performance.

6. Is reflective in an organisation's willingness to learn from errors, incidents and accidents.

7. Is relatively enduring, stable and resistant to change.

Table 1: (Wiegmann., et al. 2002) Common Themes in Cultural definitions.

The debate about culture, safety culture and food safety culture can often be perceived as three exclusive initiatives and will reinforce, quite wrongly, that food safety culture is ring-fenced purely to those who would actively work with food [32]. Furthermore, there equally appears to be additional mixed perceptions that an organisation's 'safety climate' addresses issues associated with employee attitudes towards safety. Whilst safety culture is occupied with employees' prevailing values within the organisation management need to recognise that the so-called three labels, namely safety culture, food safety culture and safety climate, collectively establish an organisation's holistic culture [33]. To treat them as separate entities is folly, as one need only refer to the media in repeatedly covering food safety accidents and incidents. Let us not forget that an organisational culture like a spore, will manifest itself and without due management attention, all too often germinates into a workforce, which fails to adhere to FSMS and actively works against the wellbeing of the organisation. Such a scenario is often referred to as a counter culture [34] and once established is very difficult to eradicate.

\section{Methodology}

Having gained clearance from the University of Sunderland Ethics Committee, five UK major food manufacturers agreed to anonymously participate in the research exercise to discuss 'BREXIT and the Implications of Food Safety Cultural Compliance in the Food Manufacturing Sector'. A sample size of 15 executives/managers (three senior executives/managers from each of the five food manufacturers) would be identified in role title only. A mixed method approach was implemented via the qualitative analysis of 15 semi-structured interviews and 3 focus groups consisting of five executives/managers. A decision was made to group the questions utilising the five key themes identified within the UK Health and Safety Executive's [20] namely Control, Co-operation, Communications, Competence and Capabilities. However, it was felt that com- petence and capabilities could be grouped together as one theme, thus, four themed semi-structured questions were presented to the participants to prompt informed responses. Thematic analysis was subsequently adopted to synthesize strategic and operational issues and to capture the anecdotal comments concerning food safety culture.

\section{Data Analysis and Discussion}

Theme 1: Control

Management made repeated reference to the importance of having a food safety strategy and the vital role that management play in personally getting involved with food safety related activities as supported by Draft [35]. However, there was little detail on employee involvement in the development of a company's strategy and there was a clear inference that a good food safety strategy is aimed at avoiding prosecution and jeopardising key accounts rather than energising the company culture with its associated benefits, such as enhanced morale, reduced non-compliance and the generation of innovative solutions as supported by Casey., et al [33]. This is indicated by the statement below:

Managing Director: "We work in a high risk operation. There are more food safety techniques and methods than you can shake a stick at. But if we get it wrong, the press will be all over us".

Commentary supported the vital role management played in their operations and supported the views of Yiannas [36]. However, commentary repeatedly made reference to the importance of control procedures and disciplinary measures for non-compliance. There was no reference to support the views that effective leadership and management styles will foster a proactive culture [37]. Furthermore, the control procedures failed to fully exploit the benefits of staff suggestions, ideas forums and other innovative methods to capture the views and ideas of their employees [38], as indicated by the statements below:

Operations Manager: "It is a management responsibility to formulate the food safety strategy and for our employees to abide by those instructions. We have strict disciplinary procedures for those who do not follow the rules".

The feedback associated with operational control measures was contradictory. For instance, all participants emphasised that their control procedures were effective. However, key examples cited failed to appreciate the consequences when there was a clear deviation from procedures, such as breaches in safety policy as noted by Denison [39]. There were several examples which indicated that if staff felt under pressure to meet production targets then procedures would be deliberately overridden and compromised, such as running out of time to clean down their workstations or production runs, thus leaving the clean down operations for the next shift that notably caused tension between shifts and the safety culture, as raised by Geller [40]

In addition, if auditing reports reflected non-conformance to procedures then this was not openly made available to current and prospective clients. This obviously sent mixed messages to subordinates concerning the importance of a transparent food safety culture [41]. There was also reference made to the style of safety management, in that a 'difficult manager' would result in employees simply following instructions despite knowing that such in- 
structions would conflict with company policy. However, in keeping quiet they would avoid unnecessary conflict with management despite the potential cost to the company during a third party audit, as highlighted by Griffith [42]. Thus, concerning the theme of control on food safety culture, despite the good intentions of senior management, there were clear examples to suggest that safety culture is fine during quiet periods but when staff operate under pressure, productivity takes precedence over safety culture. Such a 'switch on and off approach' to safety culture, which is often masked at an operational level, will no doubt erode employee buy-in concerning the importance of a proactive safety culture, as supported by Lee [43]. The above issues are reflected in the statements below:

Quality Assurance Technical Manager: "We are often instructed in not showing retail clients and food safety auditors the full set of micro results".

Manager of Operatives and Hygiene Staff: "We do not get enough time to clean down equipment and in particular when a product has been running with allergens and the next product is allergen free. there was not enough time between the changeover to carry out a full clean as defined by the procedure".

Plant Manager: "It is not uncommon for employees to maintain that the company has systems in place to encourage suggestions for saving money and efficiencies but rarely run the same systems to improve food safety culture".

\section{Theme 2: Co-operation}

Feedback from participants collectively stated that UK food manufacturers often rely on a multi-cultural workforce to resource their operations and this was supported by the views of Griffith., et al [44]. On a positive note, they stated this has alleviated a skills shortage or unwillingness to work in food manufacturing with UK nationals [14]. However, the cultural ethnicity and literacy levels have compounded the challenges that they face, as food manufacturers, in the pursuit of nurturing cohesive operational activities amongst a diverse workforce [8].

Participants indicated that despite offering literacy classes, the standards of English were quite low. This has manifested into a situation where those interviewed have adopted a 'tell and sell' culture, in which management mechanistically tell: inform the workforce via work instructions [45]. There is an expectation that employees will conform via the 'selling' which takes the form of monetary incentives such as bonus systems and unlimited access to overtime.

The corollary of such an approach has been successful in resourcing operations but in doing so has nurtured a workforce predominately motivated by money and the establishment of group dynamics with power struggles and a substantial amount of a manager's time is spend instructing the workforce [46]. Such a strategy hinders the long term dynamics in fostering team culture with the added benefits such as peer support, a sense of camaraderie, job satisfaction and a genuine feeling that management care about their wellbeing [47].

A significant issue highlighted by many participants, focused on the importance of a 'company management style'. Evidence suggested that whilst management talked about their support of democratic management practices via HACCP teams, Tool box talks and ideas forums in the pursuit of co-operation [48]. However, due to operational demands, management styles have in specific instances degenerated into an autocratic approach. This has resulted in employees simply agreeing with their line manager to avoid conflict. Despite knowing such instructions would contravene company policy and food safety legislative standards, the problem would also be exacerbated when senior management failed to confront poor management practices in the excessive use of their authority and power [49]. Examples identified that compromised a culture of co-operation are noted below:

Internal First Party Auditor: "It is not uncommon for companies to provide food safety training and measure how well the trainer has performed but never measure and manage the attitude of the delegates on the course".

Food Safety Training Manager: "When training, you often get managers and factory workers in the same sessions. If a manager has a bad attitude, then this affects the learning dynamics and compliance concerning day to day operations. The problem is that senior managers don't challenge their negative attitude and this obviously affects the morale of the staff".

Director: "Food safety is the responsibility of the Technical Manager and it is his role to police compliance".

Nurturing a culture of co-operation cannot be achieved without the genuine sustained support of both management and employees. This is by no means an easy feat given the work pressures and ethnic dynamics [49]. However, with fair and consistent management practices which listen and connect with their workforce via effective motivation strategies such as employee praise, recognition and dialogue [50]. In doing so, research suggests that these are the cultural seeds which will flourish, as evidenced in a reduction of customer complaints and product recalls, and stronger team dynamics in shaping the business's food safety culture.

\section{Theme 3: Communications}

There was a common currency in senior management feedback concerning the overarching importance of communications that echoed the views of Griffith., et al. [44] who stated that 'food safety communications is a measure of quality of the transfer of food safety messages and knowledge between management, supervisors and food handlers'. There was a collective agreement that communications in the food industry is critical, particularly in high risk operations. For instance: 
Operations Manager: "We are a high risk operation; without effective management communications our workforce would not know what to do and the consequences could shut our business down".

However, despite the importance of a company communications policy to standardise food safety communications [51], none of the organisations consulted either cited or made reference to such a policy as a vehicle to reinforce the company food safety culture. Much of the commentary focused on communications in the form of management instruction and cited examples such as team briefings and tool box talks, but comments failed to emphasise the importance of communication to enhance committed behaviour towards a healthy food safety culture, through employee feedback or direct involvement in food safety initiatives [52]. It was in the main driven by management as a one directional, top down communication. For instance:

Production Manager: "Eighty per cent of our workforce are not UK nationals and their levels of English are poor. A substantial amount of our managers' time is spent ensuring employees follow our policy and management instructions".

Senior management felt confident when divulging their company food safety policies and procedures. But there was a distinct lack of emphasis in mechanisms to capture the views of their employees and certainly no evidence of staff suggestions that had reinforced the company food safety culture [53]. Hence, their feedback failed to highlight the fact that a critical factor in communication is for management to observe and listen to the views of the workforce [54]. For instance:

Factory Supervisor: "We recognise the importance of employee feedback but when we are under pressure to maintain production runs, its difficult to set time aside to ask people what they think".

In contrast to the formal procedures concerning food safety, there were several comments made towards the end of the interviews that contradicted initial statements. It would appear that the importance of food safety cultural compliance would dissipate when it reached the production lines or operational staff. This was particularly evident when staff were under pressure to ensure that their shift targets were achieved. There was also evidence to suggest that operational errors or a deviation from procedures went unrecorded so as not to compromise the companies' profits. For instance:

Senior Manager: "When sales margins are tight, it has been known to overfill bags that contain frozen prawns by adding extra ice in order to reduce the quantity of prawns".

Production Manager: "My sales team have a set budget for cheese content which sets out the amount of protein, moisture and fat in each product. When fat content does not meet legal requirements, production staff are instructed to meet the budget not the legislation".
Operations Manager: "Quite often when staff are under pressure to meet production targets they simply follow their shift supervisor's instructions even when this means cutting corners, particularly during clean down".

It is commonly supported that effective food safety communication with employees takes sustained effort [55]. Organisations need to transparently demonstrate informed $360^{\circ}$ communications, in which employees have a voice that is both recognised and evidenced in the enhancement of food safety initiatives [56]. Aristotle aptly stated three principles of communication, namely 'logos' (presenting a clear and rational argument), pathos (using emotion) and ethos (establishing credibility) and it is still very relevant in today's food organisations [57]. Management's failure to proactively monitor both the clarity and effectiveness of its communication channels will do doubt corrupt or erode its corporate food culture ethos.

\section{Theme 4: Competence}

All participants not only stressed the importance of food safety training but indicated that non-compliance with food safety, such as improper food handling, contaminated hand contacts and production runs was attributable to a general lack of food safety knowledge [58]. In support, training records suggested that all food manufacturers had set up training regimes to both inform and educate their workforce. Management emphasised the investment that their companies had injected to support their commitment to training. Whilst this was evident, the majority of training was delivered in-house via HR trainers and such courses in the main were not accredited and did not exploit the benefits of sourcing external training to share best practice and training pedagogies [59]. In addition, much of the training involved procedural and food safety training but did little to explore 'food safety culture and its importance [33].

There also appeared a disconnection between training and operational activities, in the sense that there was very little evidence of tracking or auditing the effectiveness of competencebased training once delegates had left the training sessions. This is obviously a vital audit procedure to refine bespoke training programmes against the workforce competence levels [60]. Hence, in the majority of cases, operatives would exit training and return to production lines without meaningful discussions or updates between supervisors and trainers concerning the specific competence levels of employees. Whilst there was audited evidence of spot checks, this in the main was a mechanistic process to check compliance and failed to reinforce the importance of a safety culture [61]. This issue was further compounded due to the lack of repeat training to ensure competence levels were maintained [62]. For instance:

Factory Manager: "Whilst we offer training, some supervisors do not promote food values and principles in the workplace. We are a 
high risk operation; there are repeated examples of unsupervised staff coming to work unshaven and not wearing beard snoods".

There also was evidence to suggest a conflict in policy, for in stance employees were instructed to attend safety training. However, there was a culture of employee reluctance as their rates of pay would be reduced or they would miss out on productivity bonuses. Hence many employees failed to fully engage in the training and were purely focused on returning back to their 'day job' [59] Whilst management were aware of a lack of engagement in training, they clearly failed to address the issue in constructive dialogue with staff. It was also interesting to note that management training was significantly lower than operatives. Furthermore, supervisor and team leader training did not focus on the importance of culture and behaviour skills development to nurture a proactive safety culture. For instance:

HR Manager: "We run an operation where over $50 \%$ of the workforce's first language is not English. However there are very few procedures and work instructions translated into different lan guages. Furthermore, due to their low literacy levels, they often fail training programmes but go back to production packaging not knowing what they really have to do".

Training Manager: "Following the delivery of food safety training to senior managers, I challenged the group on their complaisan and negative attitude. In responding, some of the comments included 'as long as we are all getting paid, what's the problem' and whilst I'm sat in this training room work is piling up on my desk".

Employee competence is critical in meeting food safety standards and the efficient running of operations. However, organisations need to ensure that their food training philosophy embraces the importance of a vibrant food safety culture. Thus, procedural training must be complemented by behavioural methodologies and learning outcomes which accommodate the literacy levels of the workforce. Participants cannot be financially disadvantaged when attending training sessions and such training needs to be followed up with active monitoring and constructive dialogue with employees and not just a tick-box exercise. Employees need to transparently comprehend the organisation's cultural values and identify the importance of training and its symmetry with operational ac- tivities. Management and employees need to both recognise and genuinely believe that true competence is fuelled through effective procedural training and the underpinning of behavioural skills, such as safety culture values and norms, communication, team building and conflict resolution $[63,64]$.

\section{Conclusion}

The winds of change are actively blowing uncertainty concerning a post Brexit future and this is affecting food manufacturers in the UK and overseas. The potential of increased trading tariffs will impose greater pressure on their financials and the threat of restricted immigration on a much dependent overseas market, are quite rightly worrying food manufacturers. Despite food manufacturers' assurances that their 'houses are in order' with robust food safety cultures, the potential for serious food safety breaches in company policy and legislation, particularly in high risk food manufacturers, is ever present.

The media constantly drip feed breaking newsworthy headlines about breaches in food safety standards, for example the ' 2 Sisters Food Group' company scandal in 2017, product recalls, such as the contamination scare of eggs from Dutch farmers in 2017, and the loss of life and serious illness due to contaminated food reaching the consumer. As was the case in 2015, with the former 'Peanut Corporation', in which nine consumers lost their lives and hundreds were made ill due to salmonella poisoning. In consequence, the company executive received a 28 year jail sentence for putting profits before safety

Such tragic events question the 'fit for purpose' food safety culture initiatives currently in operation. The paper has endeavoured to highlight the variance between company expectations and their actual operational compliance in terms of food safety culture. In consequence to those issues raised in the paper, a benchmarking template has been designed called the 'Enlighten Food Safety Model', as noted in table 2. Column 1 identifies four gateways to food safety cultural compliance. Column 2 cites core themes which constituted the make-up of each of the gateways. The final column specifies key aspirations that need to be tangibly identifiable if an organisation is to genuinely believe that food safety culture is a journey not a destination

\begin{tabular}{|c|c|c|c|}
\hline \multirow{4}{*}{$\begin{array}{c}\text { Enlighten } \\
\text { food } \\
\text { safety } \\
\text { model }\end{array}$} & Control & $\begin{array}{l}\text { Strategy Leader- } \\
\text { ship Process } \\
\text { Change }\end{array}$ & $\begin{array}{l}\text { 1. The strategic and operational framework to embed and integrate food safety } \\
\text { 2. Inspirational leadership to champion food safety compliance } \\
\text { 3. Proactive and responsive attitude towards food safety processes and issues } \\
\text { 4. Food safety reporting is used to support a food safety change agents }\end{array}$ \\
\hline & Co-operation & $\begin{array}{c}\text { Responsibility } \\
\text { Empowerment } \\
\text { Teams Recogni- } \\
\text { tion }\end{array}$ & $\begin{array}{l}\text { 1. Ensuring all employees recognise and appreciate food safety responsibilities } \\
\text { 2. Empowering employees to actively participate in food safety initiatives } \\
\text { 3. Motivating team dynamics to facilitate food safety } \\
\text { 4. Providing recognition to capture and promote food safety compliance/best prac- } \\
\text { tice }\end{array}$ \\
\hline & Communication & $\begin{array}{l}\text { Vision Norms } \\
\text { Consistency } \\
\text { Feedback }\end{array}$ & $\begin{array}{l}\text { 1. Embedding the importance of food safety within the organisational vision } \\
\text { 2. Fostering food safety social norms } \\
\text { 3. The level of consistent and agreement in food safety } \\
\text { 4. Actively encourage reporting of food safety issues }\end{array}$ \\
\hline & Competence & $\begin{array}{l}\text { Training Ap- } \\
\text { praisal Devel- } \\
\text { opment Self } \\
\text { belief }\end{array}$ & $\begin{array}{l}\text { 1. Resourcing effective training and repeat food safety training programmes } \\
\text { 2. Promoting and evaluating food safety } \\
\text { 3. The adoption of food safety within the company belief system } \\
\text { 4. Food safety roles and responsibilities are clearly defined }\end{array}$ \\
\hline
\end{tabular}

Table 2: Enlighten Food Safety Model. 


\section{Bibliography}

1. Grice A. "It is time for the British people to have their say': David Cameron promises EU exit vote by 2017” (2013).

2. Alexander H. "David Cameron on Brexit, Donald Trump and why he does not regret calling a referendum" (2016).

3. Oscar Grut W. "Tesco CEO: Ex-Sainsbury boss is wrong on Brexit- but 'no deal' could push up food prices" (2017)

4. Allen K and Davies R. "FTSE 100 and sterling plummet on Brexit vote" (2016).

5. Cadman E. "Consumer spending drives UK economic growth" (2016)

6. Office for National Statistics (2016).

7. Lister S. "'Hard Brexit' would put UK food supplies at risk, leading supermarkets warn in letter to Theresa May's Government (2016).

8. Velthuijsen J W and Hoijtink P. "The impact of Brexit on the AgriFood industry (2016).

9. Elliot L. "Unimaginable for UK to leave EU without a deal, says IMF chief” (2017).

10. Finch G. "Will Brexit Trigger Exodus of Banks From London? QuickTake Q\&A" (2016).

11. Wyman 0. "One Year on from the Brexit Vote / A briefing for wholesales banks" (2017).

12. Lang T and Schoen V. "Food, the UK and the EU: Brexit or Bremain? UK: Food Re-search Collaboration” (2016).

13. Great Repeal Bill "Legislating for Brexit: the Great Repeal Bill" (2017)

14. Hyde M. "This is Deal or No Deal, Tory style. The prize is a cliffedge Brexit" (2017).

15. Adams R. "What does Brexit mean for the pigment industry?" An International News Letter Monitoring Technical and Commercial Developments in The Pigments Sector 8 (2016): 1-8.

16. Cowburn A. "Repeal Bill: What is it? Everything you need to know" (2017).

17. Sims A. "What is the difference between hard and soft Brexit? Everything you need to know" (2016).

18. Jenkins S. "Soft Brexit is the only sane option. This is no time for partisan politics" (2017).

19. Lang T., et al. "A Food Brexit: time to get real / A Brexit Briefing" (2017).

20. HSG65. "Managing for Health and Safety" (2013)
21. Food Standard Agency. “Annual Report for Incidents 2015”.

22. Mele C. "Huge Recall of Frozen Fruits and Vegetables After Listeria Outbreak" (2016).

23. Quinn B., et al. Mars recalls chocolate bars in 55 countries after plastic found in product (2016)

24. Bennis W. "On Becoming a Leader". Basic Books Publishers (2009).

25. Hsieh T. Delivering happiness: A path to profits, passion and purpose". Grand Central Publishing, New York (2010): 152.

26. Nyarugwe S., et al. "Determinants for conducting food safety culture research". Trends in Food Science and Technology (2016).

27. Powell D., et al. "Enhancing food safety culture to reduce rates of foodborne illness". Food Control 22.6 (2011): 817-822.

28. Warrick D. "Understanding, building, and changing organization cultures". In DD Warrick \& J. Mueller (Eds.), Lessons in changing cultures: Learning from real world cases. Oxford, UK: Rossi Smith Academic Publishing (2015): 1-16.

29. Deal T and Kennedy A. "Corporate cultures: The rites and rituals of organizational life". Reading MA: Addison Wesley (1982)

30. Weigmann D., et al. "Safety Culture: A review". Technical Report (ARL-02-3/FAA-02-2). Federal Aviation Administration. Aviation Research Lab Institute of Aviation: Savoy, IL (2002).

31. Weigmann D., et al. "Safety culture: an integrated review". The International Journal of Aviation Psychology 14.2 (2004): 117134.

32. Guldenmund F. "The nature of safety culture: A review of theory and research". Safety Science 34.3 (2000): 215-257.

33. Casey T., et al. "Safety Climate and Culture: Integrating Psychological and Systems Perspectives". Journal of Occupational Health Psychology 22.3 (2017): 341-353.

34. Hofstede $\mathrm{H}$ and Minkov. "Cultures and Organizations: Software of the mind: Intercultural corporation and its importance for survival". McGraw-Hill Education (2010).

35. Draft R. "Leadership Theory and Practice". Dryden Press, Hinsdale, IL (1999).

36. Yiannas F. "Food Safety Culture: Creating a Behaviour Based Food Safety Management System". New York, NY: Springer (2009).

37. Griffith C. "Do businesses get the food poisoning they deserve? The importance of food safety culture". British Food Journal 112.4 (2010): 416-425. 
38. Jaques E and Clement S. "Executive Leadership: a practical guide to managing complexity". Cambridge, MA: Carson-Hall \& Co. Publishers (1994): 4.

39. Denison D R. "Corporate culture and organizational effectiveness". New York: Wiley (1990).

40. Geller E. "In: People-Based Safety: The Source”. Virginia Beach, VA: Coastal Technologies Corp (2005).

41. Green L and Selman C. "Factors impacting food workers' and managers' safe food preparation practices: a qualitative study". Food Protection Trends 25.12 (2005): 981-990.

42. Griffith C. "Developing and Maintaining a Positive Food Safety Culture". $1^{\text {st }}$ Edition. Publisher: Highfield.co.uk Limited 1 (2014).

43. Lee T. "Perceptions, attitudes, and behavior: the vital elements of a safety culture". Health and Safety 10 (1996): 1-15.

44. Griffith C., et al. "The assessment of food safety culture". British Food Journal 112.4 (2010): 439-456.

45. Abidin., et al. "An empirical investigation of food safety culture in onsite foodservice operations". Food Control 46 (2014): 255263.

46. Taylor J. "An exploration of food safety culture in a multi-cultural environment Next steps?". Worldwide Hospitality and Tourism Themes 3.5 (2011): 455-466.

47. Richter A and Koch C. "Integration, differentiation, and ambiguity in safety cultures". Safety Science 42.8 (2004): 703-722.

48. Greenberg J and Baron R. "Behaviour in Organizations. $9^{\text {th }}$ edition. Prentice-Hall International, Englewood Cliffs, NJ (2008).

49. De Boeck., et al. "Food safety climate in food processing organizations: Development and validation of a self-assessment tool". Trends in Food Science and Technology Technology 46.2 (2015): 242-251.

50. Harvey J., et al. "An analysis of safety culture attitudes in a highly regulated environment". Work and Stress 16.1 (2002): 18-36.

51. Jespersen L., et al. "Comparative analysis of existing food safety culture evaluation systems”. Food Control 79 (2017): 371-379.

52. Rounaq N and Waterson P. "The assessment of food safety culture. An investigation of current challenges, barriers and future opportunities within the food industry. Food Control (2016): 1-10

53. Barry B and Fulmer I. "The medium and the Message: The adaptive use of communication media in dyadic influence". Academy of Management Review 29 (2004): 272-292.

54. Strohbehn C., et al. "Retail foodservice employees' perceptions of barriers and motivational factors that influence performance of safe food behavior". Food Protection Trends 34.3 (2014): 139-150.

55. Singer S J., et al. "The culture of safety: results of an organization-wide survey in 15 California hospitals". Quality and Safety of Health Care 12.2 (2003): 112-118.
56. Thill J and Courtland L. "Excellence in Business Communication". $8^{\text {th }}$ edition. Upper Saddle River, NJ: Pearson Education (2008).

57. Jones N N L., et al. "The Good the Bad and the Rehetor Rhetoric". In Management Guru Literature, Lund University (2009).

58. Fielding L., et al. "An evaluation of HACCP implementation status in UK small and medium enterprises in food manufacturing. International". Journal of Environmental Health Research 15.2 (2005): 117-126.

59. Hislop N and Shaw K. "Food safety knowledge retention study". Journal of Food Protection 72.2 (2009): 431-435.

60. Kosatsky T., et al. "Evaluation of food safety knowledge, attitudes and self-reported hand washing practices in FOODSAFE trained and untrained food handlers in British Columbia, Canada". Food Control 30.1 (2013): 150-156.

61. Ehiri J and Morris G. "Food safety control: overcoming barriers to wider use of hazard analysis". World Health Forum 17.3 (1996): 301-303.

62. Seaman P and Eves A. "Food hygiene training in small to medium-sized care settings". International Journal of Environmental Health Research 18.5 (2008): 365-374.

63. Greig JD., et al. "Outbreaks where food workers have been implicated in the spread of foodborne disease. Part 1. Description of the problem, methods, and agents involved". Journal of Food Protection 70.7 (2007): 1752-1761.

64. Howes M., et al. "Food handler certification by home study: measuring changes in knowledge and behavior". Dairy, Food and Environmental Sanitation 16.11 (1996): 737-744.

Volume 1 Issue 4 April 2018

(C) All rights are reserved by Derek Watson., et al. 